\title{
学界情報
}

\section{ISAP2013 開催報告}

\section{(International Conference on Intelligent System Applications to Power Systems)}

\author{
田村 滋 (明治大学)
}

平成 25 年 7 月 1 日〜 4 日, ISAP2013 が明治大学駿河台 キャンパスアカデミーコモンにて開催された。ISAP は電力 系統へのインテリジェントシステムを中心とした適用に フォーカスを置いており, IEEE PES (Power \& Energy Society）が技術的に協賛し 2 年毎に開催されており，今回 で 17 回目を迎える伝統のある国際会議である。

ISAP は, ESAP (International Conference on Expert System Applications to Power System) と ANNPS (International Forum on Applications of Neural Networks to Power Systems）を統合した会議であり，1987 年に設立 された。過去に日本では前身の学会として 1989 年に東京・ 神戸 (ESAP89), 1993 年に横浜（ANNPS93）で開催され た経緯はあるが，ここ20 年間は日本で開催されていなかっ た。今回, ISAP Board の依頼を受けて, 明治大学森教授が 中心となり，明治大学で開催することとなった。

今回の会議は, Tutorial 3 件, Plenary Session 3 件, Panel Session 5 件, Technical Session（表 1）から構成された。 参加者は総勢 137 名で, 日本 88 名（展示含む）のほか, 米国・台湾が各々 11 名, ポルトガル 9 名, ブラジル 4 名, その他の国ではオーストラリア，ドイツ，インド，韓国， スウェーデンなど，世界多数の国からの参加があった。

Tutorial では, Data Mining, Mean-Variance Mapping Optimization, Multi-agentに関しての最新動向を含む講義 がなされ，聴講していた学生などから積極的な質問があっ た。

Plenary Session では, 米国ワシントン州立大学教授兼ア イルランドダブリン大学教授の Chen-Ching Liu 氏による "Cyber-Physical System Security in a Smart Grid

表 1 Technical Session とその論文数

\begin{tabular}{|c|l|r|}
\hline No & \multicolumn{1}{|c|}{ セッション } & 論文数 \\
\hline 1 & Electric Vehicles & 4 \\
\hline 2 & Distribution Systems & 7 \\
\hline 3 & Smart Grid Management & 8 \\
\hline 4 & Muti-Agent Systems & 7 \\
\hline 5 & Power System Analysis & 8 \\
\hline 6 & Load \& Price Forecasting & 5 \\
\hline 7 & MicroGrid & 5 \\
\hline 8 & PV Systems & 4 \\
\hline 9 & Power System \& Plant Control & 4 \\
\hline 10 & Wind Power Generation & 4 \\
\hline 11 & Substation Automation & 4 \\
\hline 12 & Optimal Power Flow & 3 \\
\hline 13 & Power System Planning \& Operation & 3 \\
\hline 14 & Intelligent Optimization & 4 \\
\hline \multicolumn{2}{|}{ Total } \\
\hline
\end{tabular}

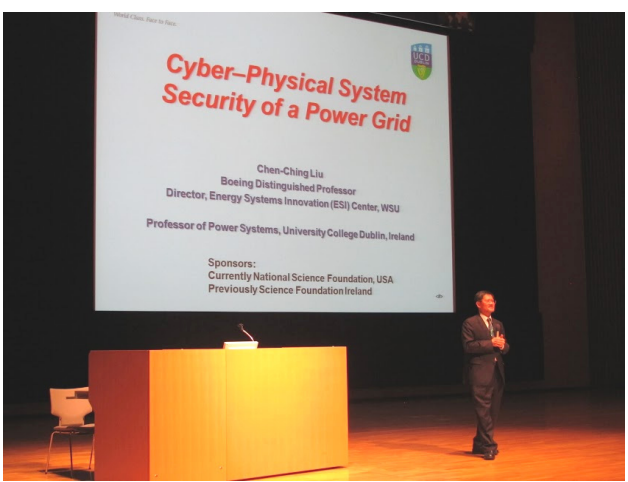

図 1 Plenary Session 風景

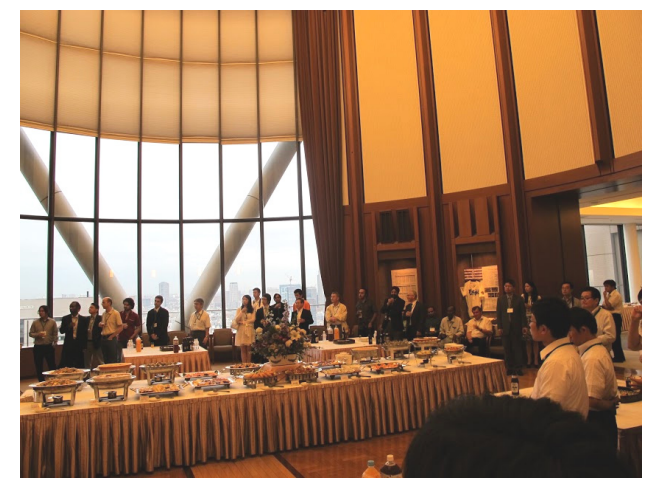

図 2 Dinner Party 風景

Environment” と題したスマートグリッドのセンサーネッ トワークと融合したサイバー空間のセキュリティの方法論 に関する講演 (図 1 参照) の他, Big data への Bayesian Networkの適用, けいはんな（京都）スマートコミュニティ のデマンドレスポンス実績の紹介の講演があった。日本の けいはんなプロジェクトは海外からの参加者の興味をそそ り，多数の質問があった。

Panel Session では, “EV Systems” など, 最新のトピッ クスに関してのパネル討論が行われた。Technical Session では表 1 に示す 14 種類, 70 件の論文発表がされ, 質疑応 答が活発になされた。論文 70 件の主な内訳は, 日本 23 件, ポルトガル 14 件, 米国 9 件, 台湾 8 件, ドイツ・インドが 各々 2 件であった。

次回の ISAP は, 2015 年 9 月にポルトガルのポルトにて 実施されることが決定された。今回の開催にあたり多大な ご協力を頂いた関係各位, ならびに参加者にこの場を借り て深謝する。また，展示およびグループ登録によりご支援 を頂いた企業, 大学並びに研究所の方々に謝意を表す。

(2013 年 8 月 19 日受付) 